\title{
COMMENT
}

\section{THE DEFENSE OF BATTERED WOMEN WHO KILL}

\author{
Rocco C. Cipparone, JR. $\dagger$
}

Domestic violence, particularly wife abuse, ${ }^{1}$ is a pervasive problem: it plagues all levels of society, from the economically disadvantaged to the rich, professional classes. ${ }^{2}$ Approximately twenty-five percent of all murder victims are killed by close family members ${ }^{3}$ and, in the majority of intrafamily cases, one spouse is killed by the other. Furthermore, it has been estimated that one-third to one-half of all women who live with a male companion will experience some form of brutality, ranging from the threat of serious harm to actual torture, at the hands of that companion.

The American legal system often has been criticized for its general ineffectiveness in dealing with wife abuse and other forms of domestic violence. In particular, several commentators have argued that the failure to adopt law enforcement policies that emphasize intervention before domestic violence reaches the point of homicide has contributed

† B.A. 1984, Saint Joseph's University; J.D. Candidate 1987, University of Pennsylvania.

1 The term "wife abuse" will be used throughout this Comment to refer to abuse of both women who are married to their mates and women who live with their abusers but are not married to them. Similarly, the terms "battered wife" and "battered woman" will be used interchangeably.

2 See L. Walker, The Battered Woman 21-25 (1979) [hereinafter L. WALKer 1979]; Comment, The Battered Wife's Dilemma: To Kill or To Be Killed, 32 HASTINGS L.J. 895, 896 (1981).

- See J. Fleming, Stopping Wife Abuse 155 (1979); Meyers, Battered Wives, Dead Husbands, Student Law., Mar. 1978, at 46, 47; A Killing Excuse, TIME, Nov. 28, 1977, at 108.

4 See J. Fleming, supra note 3, at 155 (In over 50\% of intrafamily killings, one spouse kills the other. In $52 \%$ of such killings, the husband is the killer.).

S See L. WALKER 1979, supra note 2, at 19-20; Schneider, Equal Rights to Trial For Women: Sex Bias in the Law of Self-Defense, 15 HaRv. C.R.-C.L. L. REv. 623, 624-25 (1980); see also UNITED STATEs CoMmission on Givil RIGHTS, UNDER THE Rule of Thumb: Battered WOMEN and the Administration of Justice 1 (1982) (estimating that there are well over one million battered wives in this country and that spousal violence occurs in one out of three marriages); Meyers, supra note 3, at 47 ("Estimates of U.S. families harboring wife abuse range from a low of 3 million to a high of 40 million."). 
to the escalation of wife abuse. ${ }^{6}$ Unfortunately, until improved policies are adopted and take effect, a battered woman's first contact with the legal system may be as a criminal defendant.

This Comment explores the defense in a criminal trial of a battered woman who has killed her batterer. In recent years, numerous battered women have presented a plea of self-defense to a charge of criminal homicide and have sought to introduce, in support of this claim, expert testimony with respect to the typical characteristics of women who have been exposed to a pattern of abuse by their male companions. ${ }^{7}$ These characteristics are collectively and commonly referred to as the "battered woman syndrome,"8 and courts have become increasingly receptive to expert testimony concerning the syndrome. ${ }^{9}$ Despite the admissibility of such expert testimony, there are many situations in which a battered woman defendant will have difficulty establishing a claim of self-defense in light of the traditional formulation and interpretation of the elements of self-defense.

While some commentators have argued that the law of self-defense should be modified to accommodate factual situations that do not satisfy the traditional self-defense standard, ${ }^{10}$ it is unlikely, given the longstanding history of the law of self-defense, that such a modification will occur in the near future. ${ }^{11}$ In the interim, a battered woman who has

- See J. Fleming, supra note 3, at 152-56; S. Schechter, Women and MaLe VIOLENCE 157-83 (1982); Roy, Some Thoughts Regarding the Criminal Justice System and Wifebeating, in BATTERED WOMEN 138-39 (M. Roy ed. 1977); Eisenberg \& Seymour, The Self-Defense Plea and Battered Women, TRIAL, July, 1978, at 34; Comment, supra note 2, at 902-17; Note, Does Wife Abuse Justify Homicide?, 24 WAYNE L. REV. 1705, 1710-14 (1978).

7 See, e.g., Ibn-Tamas v. United States, 407 A.2d 626 (D.C. 1979) (finding that expert testimony on battered women did not invade the province of the jury); People v. Minnis, 118 Ill. App. 3d 345, 455 N.E.2d 209 (1983) (holding that exclusion of testimony on the battered woman syndrome was reversible error); People v. White, 90 Ill. App. 3d 1067, 414 N.E.2d 196 (1980) (excluding expert testimony on battered women as irrelevant); State v. Thomas, 66 Ohio St. 2d 518, 423 N.E.2d 137 (1981) (affirming the exclusion by the trial court of expert testimony on the battered woman syndrome).

${ }^{8}$ L. Walker, The BatTered Woman Syndrome (1984) [hereinafter L. WALKER 1984] is perhaps the most thorough discussion of the syndrome.

- See, e.g., Ibn-Tamas, 407 A.2d 626. In each of the following cases, the court concluded that exclusion of testimony on the battered woman syndrome was reversible error. See Smith v. State, 247 Ga. 612, 277 S.E.2d 678 (1981); Minnis, 118 Ill. App. 3d 345, 455 N.E.2d 209; State v. Anaya, 438 A.2d 892 (Me. 1981); State v. Kelly, 97 N.J. 178, 478 A.2d 364 (1984); State v. Kelly, 102 Wash. 2d 188, 685 P.2d 564 (1984).

${ }_{10}$ See, e.g., Note, Limits on the Use of Defensive Force to Prevent Intramarital Assaults, 10 RUT.-CAM. L.J. 643 (1979) (proposing a standard that eliminates the elements of imminence and duty to retreat and introduces the element of necessity).

11 See, e.g., Rittenmeyer, Of Battered Wives, Self-Defense and Double Standards of Justice, 9 J. CRIM. JusT. 389, 392 (1981) ("To advocate . . . a radical change [in the law of self-defense] by means of judicial action is at least a cavalier response to a 
killed her batterer-but who cannot establish the traditional elements of a self-defense claim-faces the prospect of a criminal homicide conviction. This Comment advocates that in such a situation a battered woman should consider presenting a defense of temporary insanity as an alternative to a claim of self-defense. In particular situations, the former will have a greater possibility of success than the latter. ${ }^{12}$

Part I of this Comment chronicles the phases of a typical battering relationship and describes the battered woman syndrome. Part II presents the traditional and most common formulation of the legal elements of self-defense and discusses situations in which a self-defense plea by a battered woman who has killed her batterer is likely to be successful. The discussion then turns to situations wherein such a plea by a battered woman is likely to be unsuccessful. Part III advocates the presentation of a defense of temporary insanity by a battered woman for whom a claim of self-defense is likely to be unsuccessful. Part IV addresses the potential ramifications of presenting a temporary insanity defense-particularly the possibility of commitment to a mental health facility after an acquittal by reason of insanity - and argues that for the battered woman so acquitted, this possibility can be minimized.

\section{The Battering Relationship and the Battered Woman SYNDROME}

\section{A. The Battering Cycle and its Phases}

In many cases, the defense of a battered woman accused of criminal homicide will be strengthened if the defendant can establish that she has been subjected to the cyclical pattern of physical and psychological abuse now commonly referred to as the "battered woman syndrome." Dr. Lenore Walker, perhaps the foremost authority on the syndrome, ${ }^{13}$ has described the recurring stages of violence that charac-

recently discovered social phenomenon, and at most, an argument for usurpation of the democratic prerogative by the judiciary.").

12 Implicit in the argument for an alternative defense for battered women who kill in a situation in which the traditional requirements of self-defense are not met is the belief that most battered women who have killed their batterers should not be punished for their actions solely because the elements of self-defense as traditionally and presently formulated cannot be established.

$18 \mathrm{Dr}$. Walker is a licensed psychologist whose description of the battered woman syndrome is based on her studies of and interviews with battered women. See L. WALKer 1984, supra note 8, at 1-4. Dr. Walker has also testified as an expert witness in numerous spousal homicide cases, including Ibn-Tamas v. United States, 407 A.2d 626, 631 (D.C. 1979); Hawthorne v. State, 408 So. 2d 801, 805 (Fla. Dist. Ct. App. 1982), and is an often cited authority on the subject. See, e.g., Kelly, 97 N.J. at 193-95, 478 A.2d at $371-72$. 
terize a battering relationship. ${ }^{14}$ The battering cycle has three distinct phases: a period of tension-building, followed by an acute battering incident, which is in turn followed by a period of calm, loving respite. ${ }^{15}$

Phase one, the tension building stage, is characterized by "minor" battering incidents, during which the woman, in order to prevent the violence from escalating, attempts to be as complacent as possible. ${ }^{16}$ Battered women report that during this phase the psychological torture is more difficult to handle than the physical harm. ${ }^{17}$ In fact, many battered women report that the psychological effects of the battering relationship are more devastating and debilitating than the severe physical injuries that they often sustain. ${ }^{18}$

Phase two, the acute battering incident, is characterized by an uncontrollable discharge of tensions that have built up during phase one. ${ }^{19}$ The batterer typically goes into a blind rage and frequently inflicts severe physical injury upon the woman. ${ }^{20}$ Usually, some external event or internal state of the batterer himself triggers the acute battering incident. ${ }^{21}$ The woman, however, may occasionally provoke a phase two incident: in some situations, as the terror and anxiety produced in the first stage increase to unbearable levels, the battered woman would rather endure an acute battering incident than live in fear of its unpredictable yet certain onset. Furthermore, she may wish to expedite the completion of the second phase in order to reach the phase of calm, loving respite, which her previous experiences with the battering cycle have led her to expect. ${ }^{22}$ Although the violence that occurs during phase two often takes various forms, the result-as in phase one-is severe psychological stress for the woman. "She does not feel the [physical] pain as much as she feels psychologically trapped and unable to flee the situation."23

14 See L. WALKeR 1979, supra note 2, at 56-70; L. WALKER 1984, supra note 8, at 95-97; see also State v. Gallegos, 104 N.M. 247, -, 719 P.2d 1268, 1271 (N.M. Ct. App. 1986) (discussing "predictable patterns" of domestic violence).

${ }^{15}$ See L. WALKER 1979, supra note 2, at 55.

16 See id. at 56.

17 See id. at 59.

18 See id. at 7,72; L. WALKER 1984, supra note 8, at 26; see also Gallegos, 104 N.M. at -, 719 P.2d at 1271 (describing the battering relationship as a "hopeless vacuum of "cumulative terror").

19 See L. WALKER 1979, supra note 2, at 59; see also State v. Kelly, 97 N.J. 178, 193, 478 A.2d 364, 371 (1984) (describing the transition from phase one to phase two of the battering cycle).

20 See L. WALKER 1979, supra note 2, at 60.

21 See id; see also State v. Gallegos, 104 N.M. 247, -, 719 P.2d 1268, 1271 (N.M. Ct. App. 1986) (citing drunkenness and jealousy as examples of factors which motivate a man to initiate a battering episode).

22 See L. WALKER 1979, supra note 2, at 62.

28 Id. at 61-62 (emphasis added); see also L. WALKER 1984, supra note 8, at 26 
The third and "final" stage is characterized by kind, contrite, and loving behavior on the part of the batterer, who, realizing that he has gone too far, attempts to reconcile himself to the woman. ${ }^{24}$ The batterer is convinced, and the woman convinces herself, that the violence will not recur. ${ }^{28}$ The man's loving behavior, and the woman's belief that such behavior will continue, often persuade a battered woman to remain with her batterer. Inevitably, however, the period of loving respite ends and merges into a period of minor battering. The cycle begins again. ${ }^{26}$

\section{B. Characteristics of Battered Women ${ }^{27}$}

Several characteristics are common among women who have been subjected to repeated physical and psychological abuse by their mates. These traits relate to the state of mind of battered women and the typical ways in which such women react to various situations. A battered woman commonly experiences feelings of low self-esteem. In fact, she often blames herself for the batterer's behavior. ${ }^{28}$ It is also common for a battered woman to experience severe stress reactions such as anxiety, depression, fear, and general suspiciousness. She often believes that no one, including even herself, will be able to resolve her predicament. ${ }^{29}$ This feeling of helplessness stems from, among other things, society's reluctance to involve itself in marital affairs ${ }^{30}$ and the batterer's con-

(stating that battered women repeatedly asserted in interviews "that the psychological degradation and humiliation was [sic] the most painful abuse they suffered").

24 See L. WALKER 1979, supra note 2, at 65.

${ }^{25}$ See id. at 65-67.

${ }^{28}$ See id. at 69.

27 Exactly how many times a woman must be subjected to physical abuse by her male companion in order to be considered a battered woman is debatable. For purposes of her research, Dr. Walker considered any woman who had been through the battering cycle at least twice to be a battered woman. See L. WALKER 1979, supra note 2 , at xv. Whether a woman is suffering from the effects of the battered woman syndrome should be a question of fact to be resolved at trial.

${ }^{28}$ See L. WALKER 1979, supra note 2, at 31-35 (listing nine characteristics of battered women); see also J. FLEMING, supra note 3, at 81-95 (noting that characteristics common among battered women include emotional and economic dependence, and adherence to traditional value systems, and that battered women often feel guilt, isolation, fear, ambivalence, shame, and helplessness); L. WALKER 1984, supra note 8, at 75-85 (presenting the results of a psychological study of battered women).

29 See L. WALKER 1979, supra note 2, at 31-35; see also J. Fleming, supra note 3 , at $81-95$.

so See, e.g., State v. Kelly, 97 N.J. 178, 192, 478 A.2d 364, 370 (1984) (discussing the unwillingness of law enforcement agencies to pursue wife beating cases); see also Gelles, No Place to Go: The Social Dynamics of Marital Violence, in BaTTERED WOMEN, supra note 6, at 46, 55-57 (describing third parties' reactions to spousal violence); Comment, supra note 2 , at 897-99 (describing the historical view that a husband had a right to discipline his wife). 
stant reinforcement of the notions that he is the dominant figure in the relationship and that she is totally dependent upon him and him alone. ${ }^{31}$

Psychologists have applied the social learning theory of "learned helplessness" as a rationale for behavioral patterns such as those common among battered women..$^{32}$ As applied to wife beating, the theory of learned helplessness predicts that a woman who is repeatedly beaten by her male companion will eventually accept the battering behavior as unavoidable and thus will develop a feeling of helplessness. ${ }^{33}$ Once this feeling of helplessness takes root, the battered woman frequently generalizes her inability to control the beatings into a feeling of helplessness with regard to all aspects of her relationship with the batterer. ${ }^{34}$ The process of victimization experienced by a battered woman may be perpetuated to the point of psychological paralysis: even where options of escape or avoidance exist, the woman may be unable to act on or even perceive the existence of such options. ${ }^{95}$

\section{Self-Defense and the Battered Woman Who Kills}

Battered women who have killed their batterers increasingly are asserting claims of self-defense. ${ }^{36}$ In many instances, such a defense will

s1 See L. WALKER 1979, supra note 2, at 11-13 (surveying patriarchal societal conventions and the expressions of such conventions by batterers).

${ }^{32}$ See J. Fleming, supra note 3, at 93 (In the seminal learned helplessness experiments, animals subjected to repeated and nonconditional pain stimuli "learned" to ignore avenues of escape, even when escape was made readily available.).

ss See id. at 93-95; L. WALKER 1979, supra note 2, at 48-50; see also L. WALKER 1984, supra note 8, at 86-94 (applying the theory of learned helplessness to battered wives).

st See L. WALKER 1979, supra note 2, at 47-50 (Battered women frequently express the sentiment: "No matter what I do, I have no influence."). Id. at 50.

${ }^{35}$ See id. at 43; see also J. Fleming, supra note 3, at 94 (noting that a woman's perceptions need not be accurate for the theory of learned helplessness to work); L. WALKER 1984, supra note 8, at 86 (noting that, like studies of animals, studies of humans have shown that perceptual distortions occur as the result of an inability to predict the success of one's actions).

se See Ibn-Tamas v. United States, 407 A.2d 626 (D.C. 1979); Ward v. State, 470 So. 2d 100 (Fla. Dist. Ct. App. 1985); Terry v. State, 467 So. 2d 761 (Fla. Dist. Ct. App. 1985); People v. Minnis, 118 Ill. App. 3d 345, 455 N.E.2d 209 (1983); People v. White, 90 Ill. App. 3d 1067, 414 N.E.2d 196 (1980); State v. Hodges, 239 Kan. 63, 716 P.2d 563 (1986); State v. Kelly, 97 N.J. 178, 478 A.2d 364 (1984); State v. Gallegos, 104 N.M. 247, 719 P.2d 1268 (Ct. App. Ct. App. 1986); State v. Thomas, 66 Ohio St. 2d 518, 423 N.E.2d 137 (1981); State v. Hill, 287 S.C. 398, 339 S.E.2d 121 (1986). See generally Frank, Driven to Kill, A.B.A. J., Dec. 26, 1984, at 25, 26 (the . battered woman syndrome is most commonly presented as evidence in conjunction with a self-defense plea); Comment, supra note 2, at 917-18 (attorneys have recently attempted to assert justifiable homicide to exculpate women who fight back in selfdefense). 
be successful. In other situations, however, the circumstances surrounding the killing will not satisfy the traditional requirements of the law of self-defense. This section of the Comment describes the traditional elements of self-defense and examines the circumstances under which a battered woman who has killed her batterer will or will not be able to maintain a successful claim of self-defense.

\section{A. The Traditional Self-Defense Standard}

The traditional legal standard justifying the use of deadly force against another person is that the person who resorted to deadly force must have had a reasonable belief (1) that she was faced with an imminent threat of death or serious bodily harm, and (2) that deadly force was necessary to avoid or prevent such harm. ${ }^{37}$ Furthermore, in many jurisdictions the initial aggressor in an encounter may not use deadly force in self-defense unless she has effectively withdrawn from the encounter and communicated her withdrawal to the other person. ${ }^{38} \mathrm{~A}$ substantial minority of jurisdictions also require that there were no safe avenues of retreat available to the person who resorted to deadly force to repel an attack. ${ }^{39}$ Within such jurisdictions, there is general agreement that a person need not retreat from her home, ${ }^{40}$ although a few do require retreat from the home-when it can be safely had-if the assailant is a co-occupant of the home. ${ }^{41}$

s7 See W. LaFave \& A. ScotT, Griminal Law 454 (2d ed. 1986). Examples of state statutes that embody the traditional legal standard include: Mo. ANN. STAT. $\S 563.031$ (Vernon 1979); N.J. STAT. ANN. § 2C:3-4a (West 1982); 18 PA. Cons. STAT. ANN. \& 505(a) (Purdon 1983).

s8 See W. LAFAvE \& A. SCOTT, supra note 37, at 459-60. For examples of state statutes requiring withdrawal and communication of withdrawal, see CoNN. GEN. Stat. AnN. § 53a-19(c) (West 1958); Mo. AnN. Stat. § 563.031 (Vernon 1979); N.Y. Penal Law $\S 35.15(1)$ (b) (McKinney 1975).

so See W. LAFAve \& A. ScotT, supra note 37, at 460-61; Note, supra note 10, at 653-54. Statutes containing this requirement include ConN. GEN. STat. AnN. § 53a-19(b)(1) (West 1958); DEL. Code ANN. tit. 11, § 464(e)(2) (1979); N.H. Rev. Stat. ANN. \& 627:4III(a) (1986); N.J. STAT. ANN. \& 2C:3-4(b) (West 1982); N.Y. Penal Law \& 35.15(2)(a) (McKinney Supp. 1986); 18 Pa. Cons. Stat. Ann. $\S 505(\mathrm{~b})(2)(\mathrm{ii})$ (Purdon 1983).

10 See W. LAFAVE \& A. SCOTT, supra note 37, at 460-61; Note, supra note 10, at 654 . State statutes that generally do not require retreat from the home include Conn. Gen. Stat. Ann. § 53a-19(b)(1) (West 1958); Del. Code Ann. tit. 11, $\S$ 464(e)(2)(a) (1979); N.H. REv. STAT. ANN. § 627:4III(a) (1986); N.J. STAT. ANN. $\S$ 2C:3-4(b)(2)(b)(i) (West 1982); N.Y. PENAL LAw \& 35.15(2)(a)(i) (McKinney Supp. 1986); 18 PA. Cons. Stat. ANN. $§ 505(b)(2)(i i)(A)$ (Purdon 1983).

41 W. Lafave \& A. ScotT, supra note 37, at 461; Note, supra note 10 , at 654 . Examples of statutes that require retreat from the home when the assailant is a cooccupant are N.J. Stat. ANN. \& 2G:3-4(b)(2)(b)(i) (West 1982); 18 Pa. Cons. Stat, ANN. $\S 505$ (b)(2)(ii)(A) (Purdon 1983). 


\section{B. Situations in Which a Self-Defense Plea Is Appropriate for the Battered Woman Who Has Killed Her Batterer}

In many situations, the circumstances under which a battered woman killed her batterer will have been such that she will have little difficulty satisfying the traditional self-defense standard. In fact, in some cases, the battered woman defendant will be able to obtain an acquittal on self-defense grounds even without presenting evidence that in the past she had been assaulted repeatedly by the victim. Nevertheless, such evidence will usually be helpful in convincing the trier of fact that the defendant reasonably believed that she faced an imminent threat of death or serious bodily harm and that resort to deadly force was necessary under the circumstances.

The situation in which a battered woman's self-defense claim is most likely to be successful is one in which the defendant has killed her batterer during an acute battering incident. The severe bodily injury usually inflicted upon the woman during such an incident would alleviate any difficulty that the defendant might have in establishing that she had a reasonable belief that she was faced with an imminent threat of death or serious bodily harm at the particular instant at which she killed her batterer. ${ }^{42}$ Proof that she was faced with a present threat of severe bodily injury satisfies the imminence requirement as it traditionally has been interpreted. ${ }^{48}$ Furthermore, in light of the cyclical nature of the battering relationship, the fact that the defendant had been seriously injured in previous battering incidents reinforces the reasonableness of her belief that such harm would again be inflicted upon her during the particular attack in question. Courts have recognized that a trier of fact, in determining the reasonableness of the defendant's belief that she was threatened with imminent death or serious bodily harm, may take into account all the circumstances surrounding a killing, including the defendant's knowledge of prior violent acts by the victim. ${ }^{44}$

12 See, e.g., People v. White, 90 Ill. App. 3d 1067, 1071, 414 N.E.2d 196, 200 (1980) (stating that a claim of self-defense turns upon what transpired during the "particular instant" at which the death was caused).

13 See id.; see also People v. Dillon, 24 Ill. 2d 122, 126, 18 N.E.2d 503, 504 (1962) (emphasis added) ("The question is . . . whether the evidence shows that, at this particular instant, her husband made an unprovoked assault upon her which put her in reasonable fear of imminent death or great bodily harm which could only be avoided by stabbing him."). See generally Rittenmeyer, supra note 11, at 391 (citing commentators, cases, and statutes that interpret imminence as requiring the present ability of the attacker to carry out a threat of death or serious bodily injury).

14 See, e.g., State v. Wanrow, 88 Wash. 2d 221, 236, 559 P.2d 548, 555 (1977) (stating that facts and circumstances known to the defendant substantially before the killing are admissible). See generally Schneider, supra note 5, at 641-44 (surveying relevant cases). 
Similarly, a woman who has killed her batterer during an acute battering incident usually will be able to show that it was reasonable for her to believe that resort to deadly force was necessary to avoid the threatened harm. The natural disparity in physical strength between men and women and the relative lack of physical combat training of women substantiate the reasonableness of the defendant's use of deadly force. ${ }^{45} \mathrm{~A}$ battered woman who was unable to defend herself against prior attacks by her batterer, thereby suffering severe bodily injury, should be in a particularly good position to establish the reasonableness of her resort to deadly force. ${ }^{16}$ In most cases, therefore, the imminence and necessity requirements will not preclude a successful self-defense claim by a battered woman who has killed her batterer during an attack.

The retreat requirement that a minority of jurisdictions incorporate into their self-defense standard also will not preclude a successful self-defense claim by a woman who has killed her batterer during an attack. Because most of these jurisdictions do not require a person to retreat from her own home, which is where most battering incidents occur, ${ }^{47}$ a battered woman who has killed her batterer generally will be able to assert successfully a claim of self-defense even if safe avenues of retreat were available. Even in those jurisdictions that require retreat from one's home when the attacker is a co-occupant, it is unlikely that a battered woman who has killed her batterer during an attack in their home will be hindered in presenting a claim of self-defense. The retreat requirement has been interpreted to require retreat only when it "can be effected 'with complete safety,' and indeed with knowledge that retreat can be so effected."48 Complete safety is interpreted literally: a person is not required to retreat if in doing so she would "endure any

45 See, e.g., Wanrow, 88 Wash. 2d at 240, 559 P.2d at 559 ("[C]are must be taken to assure that our self-defense instructions afford women the right to have their conduct judged in light of the individual physical handicaps which are the product of sex discrimination."); see also Schneider, supra note 5, at 632-33 (arguing that a selfdefense standard should take into account the physical differences between men and women, and also the general lack of physical combat training received by women in comparison to that received by men).

16 See Comment, supra note 2, at 923 (arguing for recognition of prior battering experiences as support for the reasonableness of a woman's resort to deadly force).

17 See L. WALKER 1984, supra note 8, at 25, 168-69 app. A, table 11 (demonstrating that, among the battered women interviewed, the vast majority reported that battering incidents began and ended in the home).

48 State v. Abbott, 36 N.J. 63, 75, 174 A.2d 881, 887 (1961) (emphasis added); see also Model Penal Code \$ $3.04(2)$ (b)(ii) (1962) (stating that use of deadly force is not justified if "the actor knows that he can avoid the necessity of using such force with complete safety by retreating"). 
[injury] at all," no matter how slight. ${ }^{49}$ In determining whether a defendant actually had and knew of an opportunity to escape with complete safety, the trier of fact is to consider all the circumstances surrounding the killing, "including the excitement." woman being violently attacked by the batterer in the close quarters of her home, it is unlikely that there would be avenues of retreat available to her such that she could escape without any harm whatsoever or, even if there were, that she could have known of them under the circumstances. Therefore, a battered woman who has killed her batterer during an acute battering incident would have a strong claim of selfdefense.

\section{Situations in Which a Battered Woman Who Has Killed Her Batterer Will Not Have a Strong Claim Under the Existing Law of Self-Defense}

While there is a good chance that a woman who killed her batterer during an acute battering incident will be able to meet the requirements of the self-defense standard, the utility of a self-defense claim is limited to the relatively narrow range of facts discussed in the preceding section. If, as often occurs, a woman has killed her batterer during a lull in the beatings-such as when he was asleep ${ }^{51}$ or when he had his back turned ${ }^{\mathrm{b2}}$ - a claim of self-defense is likely to be unsuccessful. In particular, the current formulation of the imminence requirement will, in many situations, impede the success of self-defense claims asserted by women who have killed their batterers. ${ }^{53}$

Under the current formulation of the self-defense standard, a defendant asserting a claim of self-defense must show that she had a reasonable belief that she was faced with an imminent threat of death or

19 Abbott, 36 N.J. at 72,174 A.2d at 885 .

so Id. at 72,174 A.2d at 886 .

11 See Diliberto, A Violent Death, A Haunted Life, People, Oct. 8, 1984, at 100 (describing the case of Francine Hughes, who set fire to the bed in which her husband, who had repeatedly abused her, was sleeping).

52 See State v. Patri, No. 78-187-CR (Wis. Ct. App. Dec. 19, 1980) (LEXIS, States library, Wis. file), discussed infra notes 57-61 and accompanying text. See generally Schneider, supra note 5, at 634 ("Homicides committed by battered women frequently occur with a time lag, while the man is asleep or while his back is turned.").

os See, e.g., People v. Lucas, 160 Cal. App. 2d 305, 324 P.2d 933 (1958) (defendant convicted of manslaughter for shooting her husband after an argument during which he threatened to kill her); People v. White, 90 Ill. App. 3d 1067, 414 N.E.2d 196 (1980) (defendant convicted of voluntary manslaughter for shooting her husband who had previously beaten her); Patri, No. 78-187-CR (defendant convicted of manslaughter, apparently on the basis of evidence indicating that she shot her husband, who had abused her, in the back). 
serious bodily harm. Imminence does not mean inevitability or certainty; the fact that a battered woman might be in certain danger of having death or serious bodily injury inflicted upon her by the batterer at some future time is not legally relevant to a claim of self-defense as that defense is currently construed. Rather, the relevant factor is the circumstances at the particular instant in which the killing took place. ${ }^{.4}$ As one court has observed: "[T]hreats alone, unaccompanied by some act which induces in defendant a reasonable belief that bodily injury is about to be inflicted, do not justify a homicide. The danger which justifies homicide must be imminent and a mere fear that danger will become imminent is not enough."

The rationale behind the restrictive definition of imminence is obvious. As long as the threatened acts of violence are only anticipated future events, avenues of prevention or escape might be open to the defendant. Even if avenues of escape are not available when the danger of future harm is first perceived, they may become available before the anticipated violence occurs. ${ }^{86}$ Furthermore, the threatened harm might never occur and, even if it does, it might not rise to a level justifying the use of deadly force in response. Accordingly, a defendant asserting a claim of self-defense must show that death or serious bodily injury was imminent at the particular instant at which the killing occurred.

The consequences for the battered woman of the rigid definition of self-defense are illustrated by the case of State $v$. Patri, ${ }^{57}$ in which a woman whose husband had physically and sexually abused her repeatedly, and had threatened her life several times, was convicted of manslaughter despite her claim of self-defense. While there was significant disagreement at trial concerning the exact circumstances of the killing, ${ }^{68}$

64 See People v. Dillon, 24 Ill. 2d 122, 126, 180 N.E.2d 503, 504 (1962); see also White, 90 Ill. App. 3d at 1072, 414 N.E.2d at 200 ("[T] be determined by the trier of fact upon the evidence of what transpired during the 'particular instant' in which the death was caused."). See generally Rittenmeyer, supra note 11, at 391 (stating that judges and scholars have consistently interpreted "imminence" as referring to present rather than future danger).

ss Lucas, 160 Cal. App. 2d at 310, 324 P.2d at 936 (citations omitted). See generally Note, supra note 10, at 651 ("A threat of harm, no matter how certain, that is unsupported by the assailant's present ability to carry out that threat is not imminent and would not justify the use of defensive force.").

so See W. LAFAvE \& A. ScotT, supra note 37, at 458; Rittenmeyer, supra note 11 , at 391.

${ }^{87}$ State v. Patri, No. 78-187-CR (Wis. Ct. App. Dec. 19, 1980) (LEXIS, States library, Wis. file).

${ }^{56}$ The testimony that Mrs. Patri presented at trial, if believed, would have created a strong case for acquittal under the traditional formulation of self-defense. Mrs. Patri testified that during an argument in the kitchen her husband threatened her with a knife and followed her as she fled into the basement, where she picked up a shotgun. Mrs. Patri claimed that she shot her husband as he threatened to "shut [her] up once 
the jury apparently believed a statement made by Mrs. Patri shortly after the shooting: she told the sheriff that she had shot her husband in the back as he was leaving the couple's kitchen after a heated argument. ${ }^{59}$ Mrs. Patri claimed to have reloaded the gun, shot him again in the head, and then buried the body in a nearby shed, which she then set afire. ${ }^{60}$ Despite testimony that $\mathrm{Mr}$. Patri had menaced his wife with a knife during the argument and had repeated his threat to kill her, ${ }^{61}$ the jury apparently refused to find that the imminence requirement had been met in a situation in which the victim was walking away from the defendant at the time of the killing.

Neither the facts in the Patri case nor its result is atypical. For example, People v. White $e^{62}$ and People v. Lucas ${ }^{63}$ involved defendants who shot their husbands shortly after arguments in which the husbands had either beaten them or threatened to kill them. In each case, the defendant pleaded self-defense, yet she was convicted of manslaughter. ${ }^{64}$ It would appear, then, that under the existing law of self-defense a battered woman will not be justified in killing her batterer solely because death or serious bodily injury is likely to be inflicted in the future. $^{65} \mathrm{~A}$ battered woman who killed her batterer while he was asleep or while his back was turned ${ }^{\theta B}$ could not have had a reasonable

and for all" while advancing towards her with the knife. Id. Although the jury apparently did not find this testimony persuasive, it should be noted that there was no evidence that the shooting took place in the kitchen, and at least some corroborating evidence that it occurred in the basement. See id. Regardless of where the shooting took place, however, there was strong corrobative evidence that Mr. Patri was shot in the back. See id.

s9 See id.

6o See id. In a separate trial, Mrs. Patri was acquitted of an arson charge on the ground of temporary insanity. See id.

-1 See supra note 58 .

6290 IIl. App. 3d 1067, 414 N.E.2d 196 (1980) (The defendant, who previously had been beaten by her husband, shot him once as he came through the dining room toward the bedroom and subsequently shot him twice more.).

os 160 Cal. App. 2d 305, 324 P.2d 933 (1958) (The defendant, who had been physically abused by her husband for over five years, repeatedly shot her husband as he sat in a chair after an argument during which he had threatened to kill her.).

ot See Lucas, 160 Cal. App. 2d at 310, 324 P.2d at 936; White, 90 Ill. App. 3d at 1068,414 N.E.2d at 196.

os Several commentators have argued that the law of self-defense should be interpreted or modified to embrace situations such as those discussed in this section. See, e.g., Comment, supra note 2, at 926-30; Note, supra note 10, at 658-60. Until such modification does occur, see Rittenmeyer, supra note 11, at 392 (arguing that changes in the law of self-defense should be made not by the courts but by the legislatures), these situations must be analyzed in light of the present requirements for a successful claim of self-defense.

ot If, however, the batterer's back was turned only briefly during an attack on the woman, then the woman could have reasonably believed that death or serious bodily injury was imminent. 
belief that she faced an imminent threat of death or serious bodily harm. Her self-defense claim is therefore likely to be unsuccessful.

\section{Temporary Insanity: An Alternative Defense}

This section argues that a temporary insanity defense is a viable option for a woman who, while suffering from the effects of the battered woman syndrome, has killed her batterer. Such a defense should be considered by the defendant and her attorney ${ }^{67}$ when the circumstances surrounding the killing were such that there are serious doubts regarding the efficacy of a self-defense claim.

\section{A. The Test of Insanity}

One widely accepted ${ }^{68}$ formulation of the insanity standard is presented by the Model Penal Code (the "Code"). The Gode provides that "[a] person is not responsible for criminal conduct if at the time of such conduct as a result of mental disease or defect [s] he lacks substantial capacity either to appreciate the criminality [wrongfulness] . . of [her] . . . conduct or to conform [her] . . . conduct to the requirements of law." Under this test, if interpreted and applied consistently with the intentions of its drafters and the numerous state and federal courts that have adopted it, evidence establishing the presence of the battered woman syndrome will be extremely relevant and helpful in presenting an insanity defense for a battered woman. The Code presents a flexible and expansive test of insanity that allows the jury to obtain "a complete picture of the defendant's state of mind ... [ [and to] consider all relevant facts pertaining to the defendant's mental state at the time the act

67 A threshold question that the defendant and her attorney, with the help of experts, must consider is whether this particular woman who has killed her batterer was suffering from the battered woman syndrome. For a brief discussion of other attorneyclient considerations involved in deciding whether to present a temporary insanity defense, see infra note 101.

6s The Model Penal Code test of insanity has been adopted by a substantial number of states and a majority of federal circuits. See Note, Criminal Responsibility: Changes in the Insanity Defense and the "Guilty But Mentally Ill" Response, 21 WASHBURN L.J. 515, 523-24 (1982); see also Slicker, Current Perspectives on the Insanity Defense, CASE \& CoM., Nov.-Dec. 1985, at 22, 28 (providing a comprehensive list of states and federal circuits that have adopted the Code test in statutory or case law). Because of its substantive benefits and wide acceptance, this Comment uses the Code test to explore the presentation of an insanity defense for a battered woman who has killed her batterer. For a discussion of the tests of insanity in jurisdictions that have not adopted the Code test, see W. LAFAvE \& A. ScotT, supra note 37, at 304-30; Note, supra, at 517-22.

60 Model Penal Code $\S 4.01(1)$ (1962). 
was committed."70 The Code test therefore allows a defendant to place before the jury evidence concerning the battering relationship in general, the typical effects that such a relationship has upon the state of mind of a battered woman, and the specific effects of that relationship upon the particular defendant.

\section{B. Temporary Insanity and the Battered Woman Syndrome}

As discussed in Part I, the psychological effects of the battering relationship upon a battered woman are numerous and often more devastating than the physical abuse inflicted upon her. Ultimately, a battered woman's judgment is adversely affected by the constant failure of her attempts to improve her relationship with the batterer. ${ }^{71} \mathrm{Her}$ impaired judgment provides the foundation for a temporary insanity defense. The basic premise of such a defense would be that the defendant, at the time of the killing, suffered from severe stress and an impaired mental state as a result of the battering relationship, and that this impaired mental state caused her to kill the batterer. The causal link between the woman's impaired mental state and the killing can be established by showing that the woman viewed her predicament from a psychologically distorted perspective and thus was unable to perceive her options ${ }^{72}$ accurately, or by showing that the "woman was driven to the breaking point by the circumstances of her situation"73 and therefore was substantially unable "to conform [her] conduct to the requirements of law."74

It is important to recognize that, as used in the Code, the phrase "mental disease or defect" represents a legal concept rather than a defined medical term. Courts construing this phrase have found that it does not refer to any technical or "ad hoc definitions or conclusions as to what experts state is a [mental] disease or defect"7s and that it "was not intended to designate any specific form or forms or medical classifications of mental disease."

70 Hill v. State, 252 Ind. 601, 617, 251 N.E.2d 429, 438 (1969) (discussing the beneficial aspects of the Code test of insanity).

71 See L. WALKER 1979, supra note 2, at 42-54.

72 See supra note 35 and accompanying text.

7s Schneider \& Jordan, Representation of Women Who Defend Themselves in Response to Physical or Sexual Assault, 4 Women's RTS. L. REP. 149, 160 (1978).

74 Model Penal Code $\S$ 4.01(1) (1962).

${ }^{75}$ McDonald v. United States, 312 F.2d 847, 851 (D.C. Cir. 1962); see also United States v. Brawner, 471 F.2d 969, 983-84 (D.C. Cir. 1972) (adopting the Model Penal Code formulation of the insanity defense while retaining the definition of mental disease or defect supplied in McDonald).

${ }^{76}$ State v. Garrett, 391 S.W.2d 235, 239 (Mo. 1965) (commenting on the meaning of the phrase "mental disease or defect" as used in the Missouri statute, which 
would rob the court of its primary duty in evaluating the defense. ${ }^{77}$ The court's primary inquiry is not whether the defendant suffered from a clinical condition, but whether she suffered from "any abnormal condition of the mind which substantially affects mental or emotional processes and substantially impairs behavior controls."78

The legal concept of "mental disease or defect," therefore, clearly encompasses the battered woman syndrome as it has been defined by Dr. Walker and others. The battered woman's strong emotional attachment to and dependence upon her batterer, combined with the "learned helplessness"79 developed as a result of repeated beatings and reinforced by her failure to escape from each successive beating ${ }^{80}$ lead to perceptual distortions that alter the woman's mental and emotional processes. A woman attempting to establish that an impairment of her mental state resulted from recurrent beatings will be able to bolster her defense with evidence that battered women in general are themselves more prone to violence while in a battering relationship ${ }^{81}$ and sometimes suffer from other mental health problems which are causally linked to the battering relationship. ${ }^{82}$ Furthermore, it appears that many battered women who kill their batterers are not cognizant of the fact that they have killed until informed of this fact by a third person. ${ }^{83}$ Evidence that a battered woman was not immediately aware that she had killed her batterer should be very helpful in establishing a defense of temporary insanity on the ground that the defendant did not know what she was doing and thus was unable "to appreciate the criminality ... of [her] conduct." strike back finally ... a are the type of persons who could argue innocence under the insanity defense. In all too many cases, ... they understand little of their actions, but rather take on the characteristics of a

provides for a test of insanity substantially similar to the Code test).

${ }_{77}$ See United States v. Freeman, 357 F.2d 606, 622 (2d Cir. 1966) ("[A] test which permits all to stand or fall upon the labels or classifications employed by testifying psychiatrists hardly affords the court the opportunity to perform its duty of rendering an independent legal and social judgment.").

78 McDonald, 312 F.2d at 851 .

70 See supra notes $32-33$ and accompanying text.

80 This failure to escape can be traced to several of the characteristics of a typical battered woman, such as emotional dependence on the batterer and the belief that the situation will eventually improve. See L. WALKER 1979, supra note 2, at 65 .

si See L. WALKeR 1984, supra note 8, at 149-50.

82 See id. at 123.

ss See L. WALKER 1979, supra note 2, at 53 (Battered women interviewed by Dr. Walker "all stated they had no idea that they had killed [their batterers] until the police informed them" of what they had done.).

s Model Penal Code $§ 4.01(1)(1962)$. 
borderline psychotic."8s

Another beneficial characteristic of the Code test is that it not only takes into account the impairment of cognitive capabilities, but it also recognizes a defense on the basis of impairment of volitional capacity. ${ }^{86}$ Under the Code, criminal responsibility is not imposed when the defendant, at the time the act in question was committed, lacked "substantial capacity ... to conform [her] conduct to the requirements of law."8z The Code's formulation of the legal standard of insanity has two advantages over the older, increasingly unpopular ${ }^{\mathbf{8 8}}$ "irresistible impulse"89 test. First, the Code requires only substantial rather than complete impairment of cognition or volition. As its drafters recognized, "Nothing makes the inquiry into responsibility more unreal ... than limitation of the issue to some ultimate extreme of total incapacity .... The law must recognize that when there is no black or white it must content itself with different shades of gray."90

Under the Code test, therefore, it is unnecessary for a battered woman's volitional capacity to have been totally impaired at the time of the killing; she must only have lacked substantial capacity to conform her conduct to the requirements of law. The fact that she may have been able to function in some aspects of her life-for example, in caring for her children-does not necessarily preclude the possibility of presenting a successful insanity defense. It may be argued that, although she retained some capacity to function adequately in many aspects of her daily life, the battered woman did lack substantial capacity to control her behavior any longer in dealing with the batterer: as to this aspect of her life, she was "driven to the breaking point."91

${ }^{85}$ Meyers, supra note 3, at 48-49 (quoting Dr. Anne Seiden of the Illinois Mental Health Department).

${ }^{86}$ See Model Penal Code $\S 4.01$ comment at 157 (Tent. Draft No. 4, 1955); see also State v. Dyer, 10 Or. App. 247, 251, 518 P.2d 184, 186 (1974) (asserting that Oregon's insanity test is satisfied by a showing of "substantial incapacity to appreciate criminal conduct"); State v. Johnson, 121 R.I. 254, 262, 399 A.2d 469, 476 (1979) (recognizing that the Code provides for a defense on the ground of impairment of volitional capacity).

${ }^{87}$ Model Penal Code $\S 4.01(1)$ (1962).

88 See, e.g., Hill v. State, 252 Ind. 601, 608, 251 N.E.2d 429, 433-36 (1969) (rejecting the irresistible impulse test and other tests in favor of the more modern Code test); Johnson, 121 R.I. at 263, 399 A.2d at 474 (noting that many jurisdictions have abandoned the traditional tests in favor of the Code test). See generally MODEL PENAL CODE § 4.01 comment at 157 (Tent. Draft No. 4, 1955) ("The draft . . . accepts the criticism of the 'irresistible impulse' formulation as inept in so far as it may be impliedly restricted as to sudden spontaneous acts as distinguished from [acts] accompanied by brooding or reflection.").

${ }^{80}$ This test is described in W. LAFAve \& A. ScotT, supra note 37, at 310-17.

90 Model Penal Code $\S 4.01$ comment at 158 (Tent. Draft No. 4, 1955).

91 Schneider \& Jordan, supra note 73, at 160. 
The second advantage of the Code test is that, in contrast to the irresistible impulse test, it does not convey the "narrow and ... misleading implication that [the] crime ... must have been perpetrated in a sudden and explosive fit." ${ }^{\prime 92}$ The Code test, therefore, does not restrict the insanity defense solely to "sudden, momentary or spontaneous acts";93 it also acknowledges that mental illness may be characterized by brooding or reflection. ${ }^{94}$ As a result, an insanity defense under the Code remains a viable option for a woman who has killed her batterer in circumstances under which her actions could not be described as sudden, momentary, or spontaneous-such as when he was asleep or had his back turned. Although it would be detrimental to the success of a self-defense claim, the fact that the woman was not responding to an imminent threat of death or serious bodily injury, or that she may have reflected for some time upon her course of action, is not necessarily detrimental to the success of an insanity defense under the Code.

The advantages of the Code test discussed above make insanity an especially appropriate defense for a battered woman. A battered woman defendant can argue that successive repetitions of the battering cycle drove her to the mental breaking point, rendering her substantially unable to conform her conduct to the requirements of law. Several of the common characteristics of battered women provide support for this argument. Battered women often experience severe stress reactions that produce many different physical and psychological effects. ${ }^{85}$ In some cases, the psychological problems even lead to suicide. ${ }^{86}$ If the impaired mental state of these women can provoke suicide, certainly it can and does provoke homicide. Indeed, "[s]ome women, at the last second before killing themselves ... [turn] their rage against their tormentor." ${ }^{\prime 97}$ The fact that some battered women attempt suicide as a means of escaping a battering relationship is cogent evidence of the extent to which battered women may be blinded to lawful methods of resolving their predicament or may be substantially unable to take advantage of any such methods available to them. For many battered women, kill-

${ }^{92}$ United States v. Freeman, 357 F.2d 606, 620 (2d Cir. 1966).

os State v. Nuetzel, 61 Haw. 531, 540, 606 P.2d 920, 926 (1980) (criticizing the irresistible impulse test).

or See id; see also Freeman, 357 F.2d at 620-21 (arguing in favor of the Code test, recognizing that the irresistible impulse test has not been satisfied in "numerous instances of crimes committed after excessive brooding and melancholy by one who is unable to resist sustained psychic compulsion or to make any real attempt to control his conduct").

9s See L. WALKER 1979, supra note 2, at 72.

-o See L. OKum, Woman Abuse, Facts Replacing Myths 73, 106-07 (1986);

L. WALKER 1979, supra note 2 , at 72.

${ }^{97}$ L. WALKER 1984, supra note 8 , at 40. 
ing - whether suicide or homicide-appears to be the necessary resolution. Under the Code test, a strong argument can be made that criminal responsibility should not be imposed for actions taken by a person in the confused, tormented mental state that afflicts a battered woman.

Battered women have had at least some success in relying on a defense of temporary insanity. The case of State $v$. Patri ${ }^{98}$ illustrates how a temporary insanity defense might succeed in situations in which a self-defense claim would be likely to fail. Despite a claim of selfdefense, Mrs. Patri, a battered wife, was convicted of manslaughter for killing her husband. In a separate trial, however, Mrs. Patri, who had set fire to the shed in which she had buried her husband, was acquitted of an arson charge on the ground of temporary insanity. ${ }^{98}$ Defense counsel obviously was able to prove that Mrs. Patri was legally insane at the time she set the fire, which occurred only a short time after the killing. It is possible, therefore, that if an insanity defense had been presented at the manslaughter trial, the trier of fact would have acquitted Mrs. Patri of all charges.

An even more powerful illustration of the potency of a defense of temporary insanity is provided by the acquittal of Francine Hughes. Mrs. Hughes had been physically and sexually abused by her husband for fourteen years. One night, as her husband slept after another episode of physical and sexual abuse, Mrs. Hughes poured gasoline around the bed and then burned her husband to death. At trial, Mrs. Hughes was acquitted by reason of temporary insanity, ${ }^{100}$ despite the fact that the killing appears to have involved some reflection insofar as it took at least some planning for her to obtain the gasoline and set the fire. In short, the Hughes killing is typical of the situation described above in which a self-defense claim is likely to fail because the imminence requirement is not satisfied. Mrs. Hughes' success in asserting temporary insanity in such a situation should strongly encourage defendants in similar situations and their counsel to present a temporary insanity defense. ${ }^{101}$

os No. 78-187-CR (Wis. Ct. App. Dec. 19, 1980) (LEXIS, States library, Wis. file). This case is discussed more fully above. See supra notes 57-61 and accompanying text.

-9 See id.

${ }_{100}$ See Diliberto, supra note 51, at 100 (describing Mrs. Hughes' trial).

101 The decision to raise such a defense will, of course, have to be made by the defendant in conjunction with her attorney after analyzing the facts of her particular case. In situations wherein a traditional claim of self-defense is unlikely to succeed, however, it is essential that the defendant be informed of all the relevant aspects of the insanity defense. While the defense is frowned upon by some as stigmatizing the woman, in situations in which a self-defense claim is not a viable option it may be a tactical necessity to present an insanity defense when there is at least the possibility of 


\section{BEYOND AN INSANITY ACQUITTAL}

The previous section argued that under circumstances in which a claim of self-defense is likely to be unsuccessful, a battered woman who has killed her batterer should consider seeking an acquittal by reason of temporary insanity. Because many states provide procedures for postacquittal commitment of insanity acquittees to a mental health facility, an insanity acquittal is not the equivalent of an acquittal on the grounds of self-defense. Therefore, when evaluating the merits of presenting an insanity defense, a defendant and her counsel must consider the possibility of postacquittal commitment. This section of the Comment examines the involuntary commitment of persons acquitted by reason of insanity and concludes that a battered woman who has killed her batterer and then successfully presented an insanity defense often will be in a good position to avoid such commitment. Furthermore, even those women who are unable to avoid commitment should be able to obtain a prompt release or qualify for less restrictive means of confinement-such as outpatient treatment-in states that provide alternatives to commitment to a state mental health facility.

\section{A. Mandatory Commitment}

A minority of states have enacted statutes that require commitment of persons acquitted by reason of insanity. ${ }^{102}$ In these states, a battered woman will not be able to avoid commitment entirely. The Kansas Criminal Code, for example, requires: "When a person is acquitted on the ground that the person was insane at the time of the commission of the alleged crime, the verdict shall be not guilty because of insanity and

its success. As one article has noted, "[T]he defense attorney has responsibility to represent the alleged criminal while she ... is being processed through the criminal justice system. Not to avail oneself of every possible advantage in the construction of a defense would be to fall short of this obligation to the defendant." Pasewark \& Craig, Insanity Plea: Defense Attorney's Views, 8 J. Psychratry \& L. 413, 440 (1980).

The decision whether to present a temporary insanity defense is ultimately the defendant's. She may not feel stigmatized, or may deem any possible attendant stigmatization to be irrelevant or immaterial in the broader scope of presenting a defense to a criminal charge. One study of defendants who had raised insanity defenses found that the vast majority were amenable to its use, with only a small percentage raising even an initial objection concerning stigma. See $i d$. at 432 . This study seems to suggest that a defendant is not likely to consider the potential stigma attendant to the presentation of an insanity defense as a deterrent to raising the defense.

102 For statutes calling for some form of mandatory commitment of those acquitted by reason of insanity, see, for example, GA. CODE ANN. § 17-7-131(d) (Supp. 1985); InD. Code ANN. § 35-36-2-4 (West 1986); Kan. STAT. ANN. § 22-3428(1) (1981 \& Supp. 1986); ME. REv. STAT. ANN. tit. 15, § 103 (1980); Mo. ANN. STAT. § 552.040 (Vernon Supp. 1986); S.D. Codified LAwS ANN. § 23A-26-12 (Supp. 1986). 
the person shall be committed to the state security hospital for safekeeping and treatment." 103 The justification offered for statutes that require mandatory commitment after an insanity acquittal is that once it has been established that the defendant was mentally ill and dangerous at the time the crime was committed, it should be presumed that the defendant's condition is of a continuing nature. ${ }^{104}$ In fact, some statutes expressly establish this presumption. ${ }^{105}$

Mandatory commitment statutes, while usually upheld against constitutional challenges, ${ }^{108}$ are based on several presumptions that have little basis in fact. First, the rationale for mandatory commitment statutes presumes that an acquittal by reason of insanity establishes that the defendant was proven to have been suffering from a mental disease or defect at the time of the trial. This presumption, however, is particularly inapposite in those jurisdictions that place the burden of proof of sanity upon the prosecution once the defendant has placed her sanity in issue. An insanity acquittal in such jurisdictions may mean only that there was a reasonable doubt as to the defendant's sanity and not that she was shown to have been insane even at the time of the act. ${ }^{107}$ Although some jurisdictions apparently assume that the presentation of an insanity defense amounts to an admission by the defendant of dangerous mental illness, ${ }^{108}$ this assumption appears to be more a post hoc rationalization than an actual indication of the significance of a defendant's use of the insanity defense. In such jurisdictions, therefore, mandatory commitment is inappropriate: before a person acquitted by reason of insanity is committed to a mental health facility, there should be adequate proof that she is presently mentally ill or dangerous.

Furthermore, even if an insanity acquittal does establish that the defendant was mentally ill at the time of the act in question, it offers little insight into the mental state of the defendant at the time of her acquittal. Mandatory commitment jurisdictions presume that the de-

${ }^{109}$ Kan. Stat. ANN. § 22-3428(1) (1981 \& Supp. 1986).

104 See, e.g., In re Downing, 103 Idaho 689, 696, 652 P.2d 193, 200 (1982) (recognizing, and citing other cases which have also recognized, the presumption that an insanity acquittee's mental condition at the time of the act is of a continuing nature).

105 See, e.g., Kan. STAT. ANN. \& 22-3428(1) (1981 \& Supp. 1986).

106 See, e.g., People v. Chavez, 629 P.2d 1040 (Colo. 1981) (concluding that automatic commitment of a defendant found not guilty by reason of insanity does not violate due process of law); Downing, 103 Idaho at 689, 652 P.2d at 193 (upholding the constitutionality of mandatory commitment statutes). See generally W. LAFAVE \& A. ScoTT, supra note 37 , at $362-63$ (reviewing the constitutional arguments regarding mandatory commitment statutes).

${ }_{107}$ See Note, Commitment Following an Insanity Acquittal, 94 HARv. L. REv. 605, 611 (1981).

${ }^{108}$ See Downing, 103 Idaho at 696, 652 P.2d at 200. 
fendant's mental disability is of a continuing nature but offer no empirical support for this presumption. Moreover, because no inquiry is made as to whether the disorder from which the defendant suffered at the time of the act "was of the sort which is likely to have continued,"109 the presumption is applied with complete disregard for factual underpinnings. This presumption, then, ignores the wide variety of mental disorders that could give rise to a successful insanity defense. ${ }^{110}$ In addition, the longer the delay between the act and the verdict, the weaker the presumption of continuing insanity. ${ }^{111}$ It is essential, therefore, that an inquiry into whether the defendant's mental disorder was of a continuing nature be made in every case.

Finally, the failure to inquire into the particular disorder suffered by the defendant is to some extent inconsistent with the basic rationale for mandatory commitment. Mandatory commitment of insanity acquittees is usually justified in terms of preventive detention: a defendant who has committed an otherwise criminal act while insane is a threat to society. ${ }^{112}$ Even assuming that the defendant's insanity is of a continuing nature, however, the defendant has not necessarily been shown to be dangerous. While there is an increasing tendency for states to limit involuntary commitment to situations in which a mentally ill person poses a threat to herself or others, ${ }^{113}$ many states require commitment if the person is either mentally ill or dangerous. In those states, mandatory commitment would operate to "protect" society even from acquittees who have never been shown to be dangerous. ${ }^{114}$

Perhaps because of their potential shortcomings, mandatory commitment statutes usually provide safeguards against continued unnecessary commitment of insanity acquittees. ${ }^{115}$ Even absent such safeguards, two factors weigh heavily in favor of a battered woman being able to establish her sanity as soon as state law provides her with the opportu-

${ }^{109}$ A. Goldstein, The Insanity Defense 144 (1967).

110 See Note, supra note 107 , at 610.

111 See Figinski, Commitment After Acquittal on Grounds of Insanity, $22 \mathrm{MD}$. L. REv. 293, 301 (1962).

112 See Note, supra note 107, at 606-07.

113 See Developments in the Law-Civil Commitment of the Mentally Ill, 87 HARv. L. REv. 1190, 1202-04 (1974); see also Note, supra note 107, at 607-08 ("In general a state will not commit someone to a mental hospital without proof that he is mentally ill and dangerous to himself or others.").

${ }^{124}$ It should be noted that this section of the Comment is discussing the shortcomings of mandatory commitment as it is applied to all insanity acquittees, not just those acquitted of a charge of homicide or other violent crime. Of course, in the latter situation the requisite dangerousness would be proved.

116 See, e.g., Mo. ANN. Stat. § 552.040 .4 (Vernon Supp. 1986) (providing that an insanity acquittee, while automatically committed, is entitled to a hearing within 60 days). 
nity. First, a significant amount of time often will have passed between the commission of the act in question and the commitment hearing. The longer the interval between the act and the commitment hearing, the less support there will be for the inference that the woman is currently mentally ill or dangerous and hence a suitable candidate for commitment. The fact that she will have received treatment during her postacquittal commitment and may have received counseling before and during the trial adds support to the argument that the threat, if any, that a battered woman poses to herself or society will dissipate with the passage of time. Secondly, in a very real sense, it can be argued that the "act itself [the killing] may have effected a 'cure' of the problem."116 The woman's act was occasioned by a particular stress, the source of which has been eliminated by means of the act itself. Thus, there is "little likelihood of subsequent criminal acts." free of the battering relationship, there is usually a marked improvement in her mental health. ${ }^{118}$ Indeed, her mental health "must often [improve] before [she] is . . competent to stand trial."118 Mental health officials have noted that "when the situation of stress is relieved ... these women's disordered and unusual behavior disappears. The women return to acting very normally, usually exceptionally agreeable and conforming." 120 By the very nature of the battered woman syndrome and the battering relationship, then, a strong argument can be made that the battered woman acquitted by reason of insanity poses no threat to herself or to the health, safety, or property of others. The mental impairment of a battered woman is not "of the sort which is likely to have continued." 121

\section{B. Discretionary Involuntary Commitment}

Because most states have enacted statutes that provide trial courts with varying degrees. of discretion in determining whether a defendant who has been acquitted by reason of insanity should be committed to a mental health facility, a battered woman insanity acquittee often will be able to avoid commitment altogether. While some states provide for

116 Note, Acquittal By Reason of Insanity: Is Mandatory Commitment Constitutional?, 39 UMKC L. REv. 213, 217 (1970-71).

112 Id.

118 See Meyers, supra note 3, at 49; see also L. WALKER 1984, supra note 8, at 149-50 (noting that battered women were less prone to commit violent acts when they were not living in a battering relationship).

110 Note, supra note 107 , at 611 .

120 Meyers, supra note 3, at 49 (discussing the views of Dr. Anne Seiden of the Illinois Mental Health Department).

132 A. Goldstein, supra note 109, at 144. 
formal commitment proceedings at the end of a defendant's criminal trial, ${ }^{122}$ and others require a separate civil commitment proceeding, ${ }^{123}$ most states allow the criminal trial court to confine an insanity acquittee pending a more thorough determination of her present mental condition. ${ }^{124}$

In almost all nonmandatory commitment states, ${ }^{125}$ an insanity acquittee will not be committed unless the state can make the same showing by clear and convincing evidence of present mental illness or dangerousness that it is required ${ }^{\mathbf{1 2 8}}$ to make in civil commitment proceedings. In Alabama, for example, the trial court must decide whether there is probable cause to believe that an insanity acquittee is presently mentally ill and dangerous. If probable cause is found to exist, the acquittee is temporarily confined pending the outcome of a separate commitment hearing; otherwise, she is released. ${ }^{127}$ Other states, such as Florida, employ a similar procedure in which the trial court itself can commit the acquittee, but only after finding that she is presently manifestly dangerous. ${ }^{128}$ States such as Pennsylvania, ${ }^{129}$ wherein

122 See, e.g., AlaSka STAT. $\S 12.47 .090$ (c) (1984) (requiring an insanity acquittee to prove by clear and convincing evidence that she no longer suffers from a mental illness which could cause a danger to the public); FLA. STAT. ANN. $\S 916.15$ (West 1985) (requiring that a court find an insanity acquittee "manifestly dangerous" before ordering involuntary commitment); N.J. STAT. ANN. \& 2C:4-8(a-b) (West 1982) (providing that the commitment decision is to be made after a psychiatric examination by a doctor of the prosecutor's choice).

${ }^{123}$ For example, see Ariz. R. Crim. P. 25; Pa. Stat. AnN. tit. 50, $§ 7406$ (Purdon Supp. 1986), each of which provides that a petition must be filed for a separate civil commitment proceeding.

124 See, e.g., AlA. CODE $\S 15-16-41$ (1982) (allowing the court to order an insanity acquittee into the sheriff's custody pending a hearing, provided that the court finds probable cause to believe that the acquittee suffers from a mental illness and therefore poses a danger to herself or the public); ARK. STAT. ANN. § 41-612(1)(a) (Supp. 1983) (permitting a court to confine, prior to a commitment hearing, an acquittee who it finds may be dangerous to others); Cal. Penal CoDE $\S 1026(b)$ (West 1985 \& Supp. 1986) (allowing the court to remand custody of the defendant to the sheriff pending a final determination with respect to sanity if it appears to the court that the defendant has recovered completely); MASS. GEN. LAWS ANN. ch. 123, $\S 16(a-b)$ (West 1981) (requiring that a court order commitment pending a full commitment hearing); N.C. GEN. STAT. \& 15A-1321 (1983 \& Supp. 1985) (recognizing a court's discretion to initiate civil commitment proceedings and to issue custody orders pending such proceedings); S.C. CODE ANN. § 44-23-610 (Law. Co-op. 1976) (allowing a court discretion to initiate civil commitment proceedings and to issue hospitalization orders pending such proceedings); TEX. CODE. CRIM. PROC. ANN. art. 46.03(d) (Vernon Supp. 1986) (requiring the court to order commitment proceedings, and allowing the court to order confinement pending a hearing within 30 days, if the defendant is acquitted of a crime involving threat of serious bodily injury).

125 Alaska is an exception in that it places the burden of proof on the party opposing commitment. See AlASKa STAT. $\S 12.47 .090$ (c) (1984).

138 See Addington v. Texas, 441 U.S. 418, 431-33 (1979).

127 See Ala. Code \& 15-16-41 (1982).

128 See Fra. Stat. ANN. § 916.15 (West 1985). 
the trial judge at most can order the prosecuting attorney to initiate standard commitment proceedings, provide the greatest protection against unnecessary commitment of persons acquitted by reason of insanity.

It is important to note that in all of the nonmandatory commitment states a battered woman insanity acquittee will be able to make her arguments against commitment prior to any confinement in a mental health facility. Furthermore, in the states that require the trial court to apply the same standard as would be applied in an ordinary civil commitment proceeding, the acquittee will benefit from the stringent burden of proof imposed on the party seeking commitment. ${ }^{130}$ In those states that leave the initial decision concerning temporary confinement to the discretion of the trial court, the defendant will still have an opportunity to persuade the court that she is no longer suffering from a mental illness of sufficient severity to warrant commitment. Even if she fails to persuade the court not to order confinement pending her commitment hearing, she still will have an opportunity at the subsequent hearing to persuade the finder of fact that there is insufficient cause to justify her continued commitment.

An additional benefit of discretionary commitment proceedings is that they frequently include consideration of less restrictive means of confinement for insanity acquittees who otherwise might present difficult dilemmas for courts making commitment decisions. The availability of conditional releases and outpatient programs provides courts with an alternative to the polar choice between no observation or treatment at all and full scale commitment to a state mental institution. ${ }^{131} \mathrm{Be}$ cause the confining nature of the battering relationship was one of the primary factors that caused the deterioration of the battered woman's mental health in the first place, the nonconfining nature of outpatient treatment, in comparison with the nature of commitment to a mental health facility, may be more appropriate therapeutically for the battered woman insanity acquittee. After an insanity acquittal, the "sole concern is therapeutic."132 Furthermore, "[t]reatment without hospitalization is particularly suitable in cases where confinement would work unnecessary hardship ... and where adequate arrangements can be

129 See Pa. Stat. AnN. tit. 50, § 7406 (Purdon Supp. 1986).

180 See supra notes $122-26$ and accompanying text.

181 The following state statutes are among those that advance less restrictive means of treatment and observation as alternatives to involuntary commitment: CAL. Penal Code $\S 1026$ (West 1985 \& Supp. 1986); N.J. Stat. AnN. § 2C:4-8(b)(2) (West 1982); PA. Stat. ANN. tit. 50, $\S$ 7304(f) (Purdon Supp. 1986); Wash. Rev. CODE ANN. \& 10.77 .110 (1980 \& Supp. 1986).

138 A. GolnsteIN, supra note 109, at 146. 
made for treatment in the community."13s When there are adequate community resources for treatment, committing a woman who has young children-as battered women often do-would work an unnecessary hardship. Considering the fact that most battered women are unlikely to commit violent acts after the battering relationship ceases, as well as the fact that many of them are also mothers with children in need of care, the availability of noncommitment supervision may make the difference between prolonging the family disruption caused by spousal violence and taking the first steps toward restoring the family to normal life.

\section{CONCLUSION}

The Legislature finds and declares that domestic violence is a serious crime against society; that there are thousands of persons in this State who are regularly beaten, tortured and in some cases even killed by their spouses or cohabitants; that a significant number of women who are assaulted are pregnant; [and] that victims of domestic violence come from all social and economic backgrounds and ethnic groups "134

This statutory recognition of the widespread existence of domestic violence is potent evidence of how pervasive a problem it is. Domestic violence often results in the death of the battered spouse, but occasionally battered women kill their batterers.

These women increasingly have been relying upon self-defense as a justification for their actions, and in many situations rightly so. In light of the traditional formulation and interpretation of the requirements of the law of self-defense, however, in some situations a selfdefense plea by a battered woman who has killed her batterer is likely to be unsuccessful. In those situations, alternative defenses should be considered.

One potentially successful alternative defense is that of temporary insanity. The characteristics typically exhibited by a battered woman, collectively and commonly referred to as the battered woman syndrome, will be of enormous significance in presenting an insanity defense. Although an acquittal by reason of insanity includes the possibility of commitment to a mental health facility, strong arguments can be made

18s Leavy, The Mentally Ill Criminal Defendant, 9 CRIM. L. BuLL. 197, 242 (1973).

184 N.J. Stat. Ann. § 2G: 25-2 (West 1982). 
that such commitment is inappropriate for a battered woman. Therefore, for a battered woman who has killed her batterer in circumstances that do not satisfy the traditional requirements of the self-defense standard, a defense of temporary insanity is a viable alternative that should be considered. 